\title{
Rapid-Estimation Method For Assessing Scour at Highway Bridges Based on Limited Site Data
}

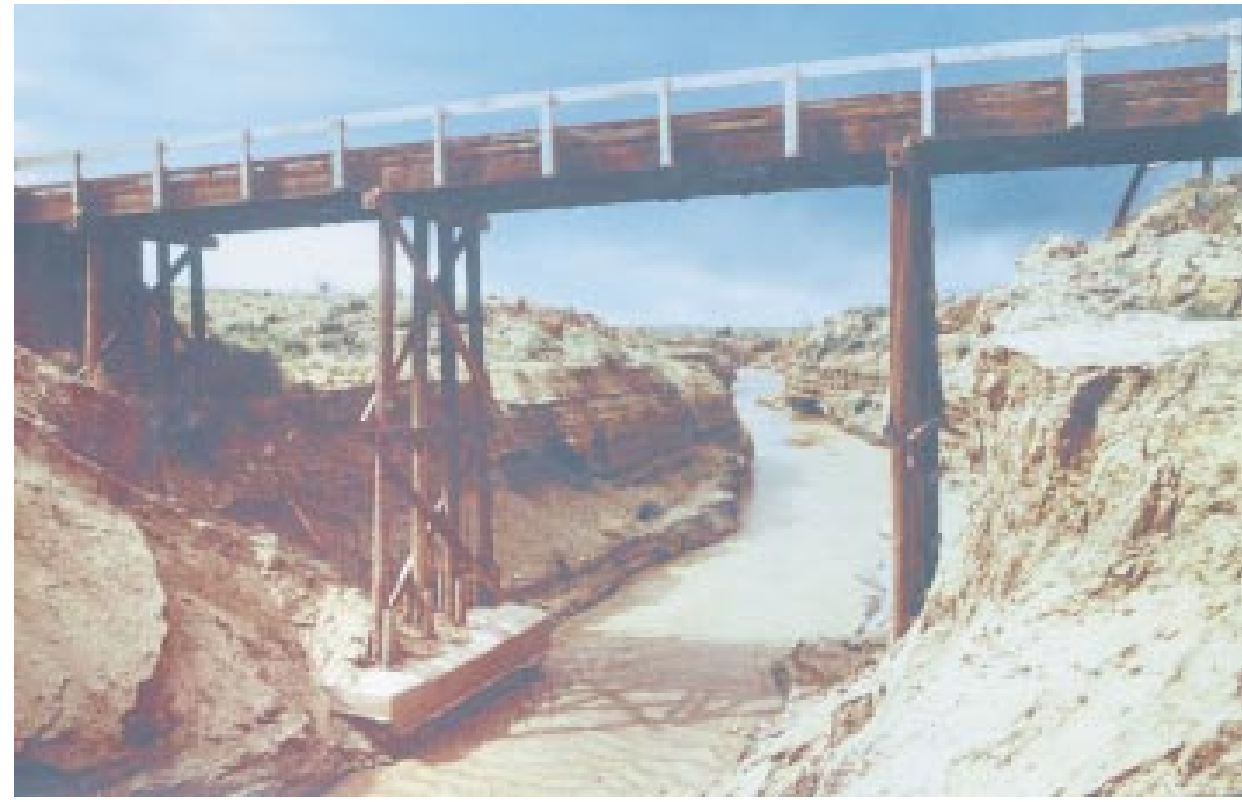

Bridge scour on Rio Puerco River, New Mexico. Photo courtesy of Steven D. Craigg, U.S. Geological Survey.

A method was developed for rapid estimation of scour depths at highway bridges based on limited site data that could be obtained at a site in a matter of hours rather than the several days or longer that is required by more detailed methods. A faster method is needed to estimate scour depths because scour assessments are required for a large number of bridges as part of a national program to inventory scour-susceptible bridges throughout the United States. Data from detailed scour analyses performed by the U.S. Geological Survey in Colorado, Indiana, Iowa, Mississippi, Missouri, Montana, New Mexico, South Carolina, Texas, and Vermont and the Montana Department of Transportation were used to develop relations between scour depth and hydraulic variables that can be rapidly measured or estimated in the field.

\section{BACKGROUND}

Scour at highway bridges involves sediment-transport and erosion processes that cause streambed material to be removed from the bridge vicinity and generally is separated into components of pier scour, abutment scour, and contraction scour. Pier scour occurs when flow impinges against the upstream side of the pier, forcing the flow in a downward direction and causing scour of the streambed adjacent to the pier. Abutment scour happens when flow impinges against the abutment, causing the flow to change direction and mix with adjacent main-channel flow, resulting in scouring forces near the abutment toe. Contraction scour occurs when flood-plain flow is forced back through a narrower opening at the bridge, where an increase in velocity can produce scour. Total scour for a particular site is the combined effects of each component. While different materials scour at different rates, the ultimate scour attained for different materials is similar and depends mainly on the duration of peak streamflow acting on the material (Lagasse and others, 1991, p. 90). Scour can occur within the main channel, on the flood plain, or both.

The most commonly used detailed method for analysis of scour (Level 2 analysis) uses hydrologic, hydraulic, and sediment-transport related engineering concepts to make quantitative scour-depth estimates. Estimation of scour depth using the Level 2 analysis requires substantial personnel and computer resources and several days or more to complete for each site. Given that almost 485,000 bridges in the United States are over waterways and may be susceptible to scour to some degree, a detailed scour analysis at all sites may not be feasible. Accordingly, the U.S. Geological Survey began a study to develop a method for rapid estimation of scour depths that would (1) require only limited, easily measured onsite data, (2) provide estimates of scour depth that would compare reasonably to estimates from detailed methods and would tend to not underestimate scour depth, and (3) provide estimates of scour depth at a given site in a few hours or less, so that scour assessments at bridges of interest might be completed in a timely fashion.

\section{DESCRIPTION OF METHOD}

Calculated scour-depth and hydraulic data from Level 2 scour analyses were used to develop a method for the rapid estimation of scour depths based on limited data that can be easily measured or estimated from a site visit. To ensure 
that the rapid-estimation method would be applicable to a wide range of geographic and hydrologic conditions, data from ten States were used to develop the method.

Although scour depths can be explicitly calculated using the Level 2 equations, complex hydraulic variables in some equations cannot be easily measured or estimated in the field. Surrogate variables that could be easily measured or estimated were substituted for the more complex variables in the Level 2 scour equations to arrive at simpler forms of the scour equations. These simpler equations were used to develop relations between scour depths and the surrogate variables. To ensure that the rapid-estimation method would tend to overestimate rather than underestimate scour depths compared to detailed methods, relations between scour depths and the selected surrogate variables were based on envelope curves rather than best-fit curves.

For example, important variables for estimation of pier scour (fig. 1) using the rapid-estimation method include pier width and length, flow angle of attack, and the average Froude number of flow in the bridge section. Froude number is a hydraulic term related to flow depth and velocity. Of these variables, pier width was the most significant. The other variables were combined with pier-scour depth to form a term called the pier scour function $(\xi)$ that could be plotted against pier width. Data from Level 2 analyses were thus plotted and an envelope curve was used to encompass the data. The envelope curve is used to determine a value for the pier scour function (fig. 2 ), which is then used to calculate pier-scour depth.

In a similar manner, envelope curves for abutment scour and contraction scour were also developed. Hydraulic variables
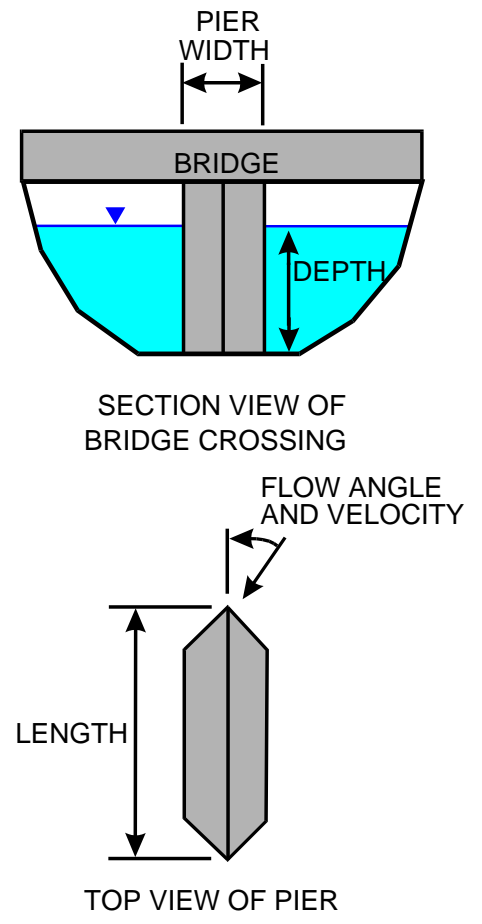

Figure 1. Variables used for estimation of pier scour.

needed to apply the envelope curves range from as few as two for abutment scour to ten or more for typical conditions of contraction scour.

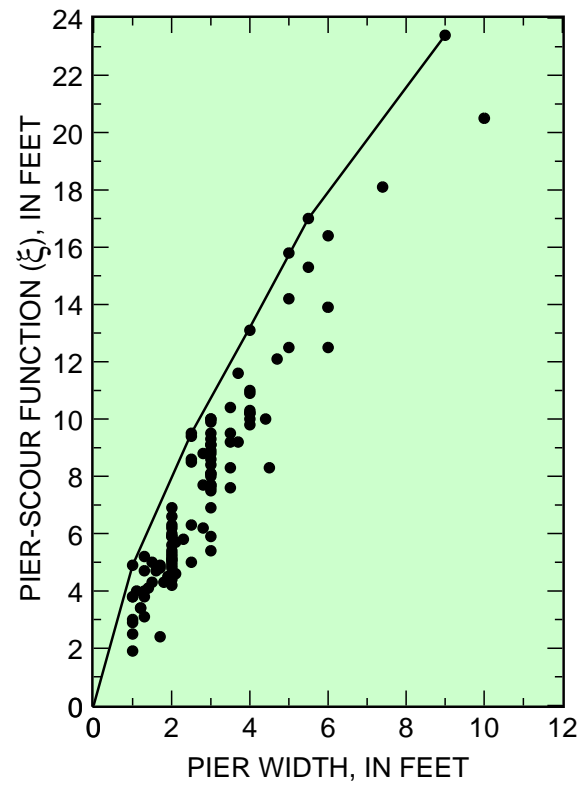

Figure 2. Envelope curve for estimation of pier scour function.
To apply the rapid-estimation method, a peak discharge having a 100 -year recurrence interval is estimated using existing USGS methods such as those described by Jennings and others (1994). The 100year discharge is divided by estimated width of flow at the bridge section to yield a term called unit discharge at the bridge. A graph developed from Level 2 data (fig. 3) is used to estimate velocity at the bridge from unit discharge, and a second graph (fig. 4) is used to estimate bridge backwater from velocity at the bridge. Backwater, the increase in flow depth upstream from a bridge (fig. 5), is used to estimate upstream flow depth and other variables required for application of the envelope curves. Figures 3 and 4 were developed from data from Montana and Colorado and may need to be modified for use in other States. Because determination of variables on the basis of figures 3 and 4 is an intermediate step in the method, best-fit relations were used so that moderate estimates of velocity and backwater result, which are then used in further steps to actually apply the envelope curves. Estimated scour depths from the envelope curves are entered on a standardized scour analysis reporting form together with various qualitative observations about hydraulic and geomorphic conditions that may affect scour. Scour prisms, based on scour depths and angles of repose for typical streambed materials, can be plotted on the design drawings as described by Richardson and others (1993, p. 46-47) to determine whether scour holes are a threat to pier or abutment foundations (fig. 6). The total scour depth used for plotting purposes on design drawings and for assessment of scoursusceptibility is contraction scour plus pier scour for piers and contraction scour plus abutment scour for abutments. 


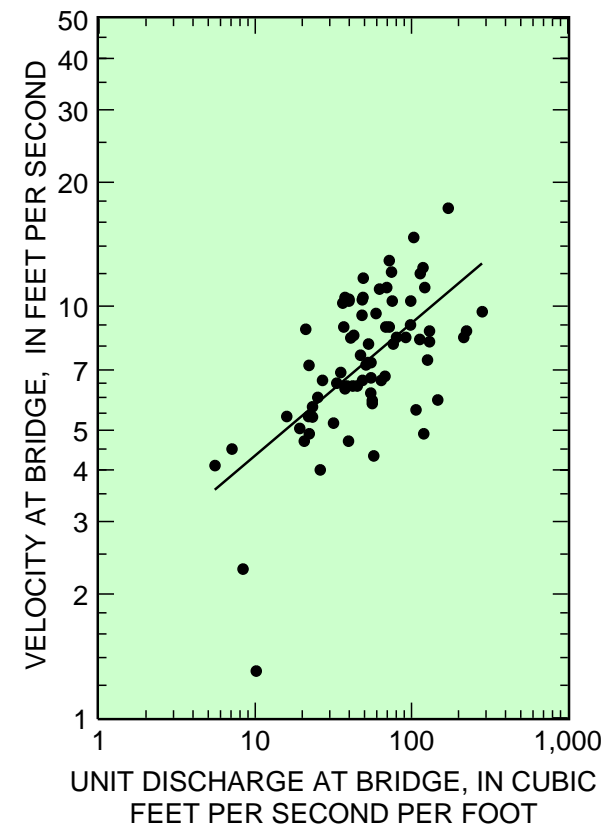

Figure 3. Graph for estimation of velocity at bridge.

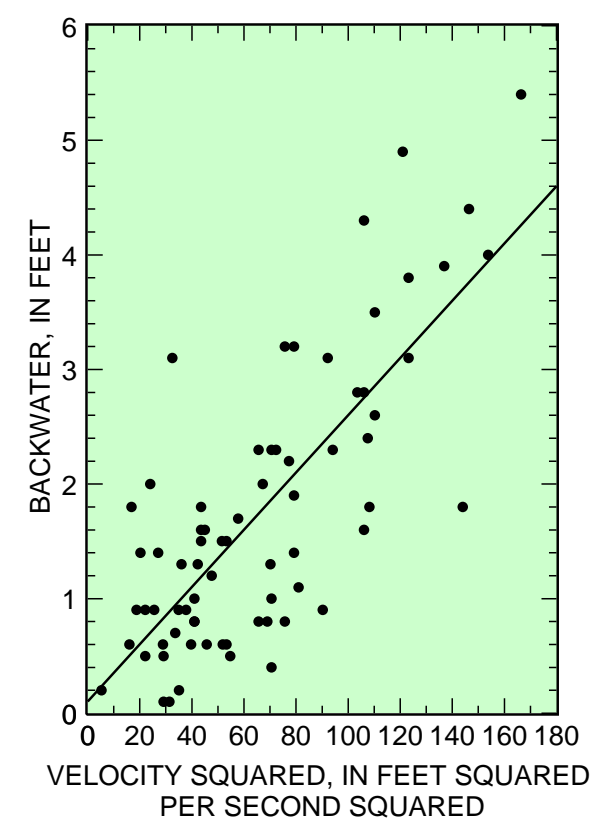

Figure 4. Graph for estimation of backwater at bridge.

\section{EVALUATION AND LIMITATIONS OF METHOD}

Two approaches were used to field test the rapid-estimation method. In the first approach, several individuals experienced in bridge scour-related fields independently applied the method to the same

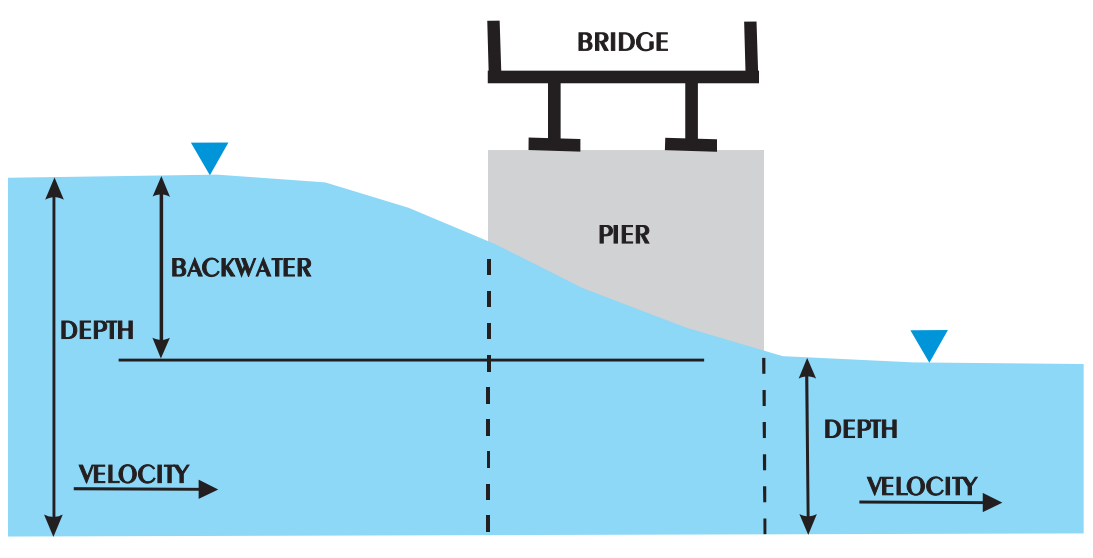

Figure 5. Side view of stream showing backwater and hydraulic variables at and upstream from bridge.

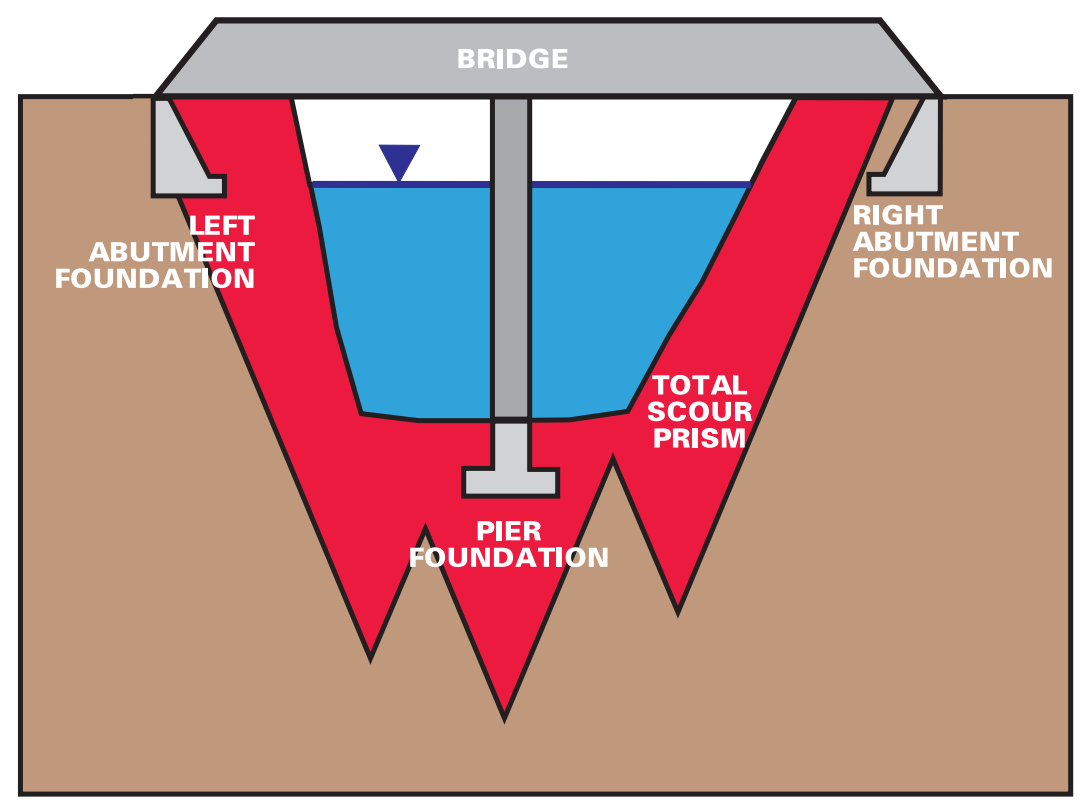

Figure 6. Sketch of scour prism showing possible threat to left abutment and pier foundations.

selected sites, and the averages of individual results were compared to results from detailed methods at the sites. In the second approach, the mean and standard deviation determined from results obtained by each individual for each site were used to obtain an indication of variability among individuals.
Results showed generally good agreement in both approaches.

\section{In addition to the two} comparison approaches used, it was also determined that for contraction scour, 28 of 33 scour-depth estimates by the rapid-estimation method equaled or exceeded corresponding 
depths calculated by the Level 2 method; for pier scour, 17 of 24 estimates by the method exceeded corresponding Level 2 depths; and for abutment scour, 55 of 66 estimates by the method equaled or exceeded corresponding Level 2 depths. On the basis of 123 separate scour components investigated by five different individuals, it was found that no more than about two hours was required to conduct and report scourdepth estimates for each bridge site. The evaluation effort described above demonstrates that the method can be successfully used to rapidly estimate scour depths at bridge sites.

Because considerable engineering judgment may be involved in applying the rapidestimation method to site-specific conditions, reasonable estimates of scour depth are possible only if the method is applied by a qualified individual possessing knowledge and experience in the fields of bridge scour, hydraulics, and flood hydrology. Although the rapidestimation method is useful for estimating scour depths to identify potentially scour-critical bridges, it does not replace more detailed methods commonly used for design purposes in the rehabilitation or replacement of bridges. The rapidestimation method is also subject to the same limitations as the more detailed methods for the estimation of scour. The development, application, and evaluation of the rapidestimation method is described in detail in the recent report by Holnbeck and Parrett (1997). This report, as well as reports describing the Level 2 method in detail (Lagasse and others, 1991, and Richardson and others, 1993) need to be read and understood before undertaking any scour assessments.

\section{REFERENCES CITED}

Holnbeck, S.R., and Parrett, Charles, 1997, Method for rapid estimation of scour at highway bridges based on limited site data: U.S. Geological Survey Water-Resources Investigations Report 96-4310, 79 p.

Jennings, M.E., Thomas, W.O., and Riggs, H.C., 1994, Nationwide summary of U.S. Geological Survey regional regression equations for estimating magnitude and frequency of floods for ungaged sites, 1993: U.S. Geological Survey WaterResources Investigations Report 94-4002, 196 p.

Lagasse, P.F., Schall, J.D., Johnson, F., Richardson, E.V., Richardson, J.R., Chang, F., 1991, Stream stability at highway structures: U.S. Department of Transportation No. FHWAIP-90-014 Hydraulic Engineering Circular 20, 195 p.

Richardson, E.V., Harrison, L.J., Richardson, J.R., and Davis, S.R., 1993, Evaluating scour at bridges (2d ed.): U.S. Department of Transportation Hydraulic Engineering Circular $18,132 \mathrm{p}$.

\footnotetext{
By Stephen R. Holnbeck and Charles Parrett
}

\section{FOR MORE INFORMATION}

USGS State representative 301 South Park Avenue Federal Building, Room 428 Helena, MT 59626-0076 (406) 441-1319 Email:dc_mt@usgs.gov

Additional earth science information can be found by accessing the USGS Home Page on the World Wide Web at http://www.usgs.gov/

\author{
For more information on \\ all USGS reports and products \\ (including maps, images, \\ and computerized data), call \\ 1-800-USA-MAPS
}

The USGS provides maps, reports, and information to help others meet their needs to manage, develop, and protect America's water, energy, mineral, biological, and land resources. We help find the natural resources needed to build tomorrow, and supply the scientific understanding needed to help minimize or mitigate the effects of natural hazards and environmental damage caused by natural and human activities. The results of our efforts touch the daily life of almost every American. 